\title{
Development of Decision Support Systems Selection of Employee Acceptance Using Weighted Product Method
}

\author{
Rancang Bangun Sistem Penunjang Keputusan \\ Penerimaan Penerimaan Karyawan Menggunakan \\ Metode Weighted Product
}

\author{
Arief Herdiansah ${ }^{1}$, Nurdiana Handayani ${ }^{2}$, Alfan Kurniawan ${ }^{3}$ \\ 1,2,3Computer Science Dept., Muhammadiyah Tangerang University, Tangerang City, Indonesia \\ Email: 1arief_herdiansah@umt@ac.id,2nurdiana.handayani@umt.ac.id,3dieyan3@gmail.com
}

\begin{abstract}
Employee selection is an activity to get human resources for a company. Researchers conducted research at PT. Gajah Tunggal Tbk where currently the selection process still uses the conventional method, the current assessment of participants uses technical and non-technical tests with interview methods but at present the company does not yet have a standardized weighting of values tested, so companies sometimes have difficulty determining who should receive from the test participants. Based on the above conditions, researchers conducted SPK design research using the WP method to assist companies in getting the right employees according to the employees' technical needs and abilities. SPK development refers to the results of data collection using qualitative and quantitative data collection methods. Development of SPK is built based on the waterfall system development model using the PHP programming language. The system testing method uses the black box method. The SPK design of employee acceptance selection generated from this study is expected to be a reference for the selection process of employees in similar industries with the place of research conducted by researchers.
\end{abstract}

Keywords: SPK, WP, Employee Selection

\section{PENDAHULUAN}

Hampir setiap tahun sebuah Perusahaan manufacturing membuka lowongan pekerjaan termasuk PT Gajah Tungal Tbk, karena dalam setiap tahun turn-over karyawan yang terjadi di perusahaan manufacturing cukup banyak. Ketersediaan karyawan terlatih yang cukup bagi perusahaan manufacturing merupakan sebuah kebutuhan bagi perusahaan khususnya dibagian produksi karena jika jumlah karyawan terlatih tidak mencukupi di bagian produksi dapat mengakibatkan penurunan hasil produksi yang dihasilkan. Dalam proses penerimaan karyawan baru saat ini perusahaan masih menggunakan metode seleksi konvensional, dimana calon karyawan akan diminta untuk mengikuti tes tertulis yang terdiri dari 
pertanyaan teknikal dan non teknikal sesuai dengan kebutuhan perusahaan. Perusahaan akan melakukan seleksi awal dengan melakukan pemeringkatan calon karyawan berdasarkan nilai hasil tes tertulis tersebut untuk selanjutnya perusahaan akan melakukan tes berikutnya yaitu test wawancara dan test kesehatan, kemudian pihak berwenang perusahaan (dalam hal ini HRD) akan melakukan kalkulasi pemeringkatan para peserta tes untuk selanjutnya ditentukanlah peserta tes yang diterima atau tidak diterima sesuai dengan kebutuhan perusahaan. Akan tetapi sering kali perusahaan tidak mendapatkan karyawan yang sesuai dengan harapan, penyebabnya adalah perusahaan sering mendapatkan karyawan yang tidak sesuai dengan keahlian yang diinginkan disebabkan karena perusahaan tidak memiliki bobot kriteria yang tetap dalam proses seleksi. Oleh karena itu perusahaan membutuhkan standarisasi pembobotan penilaian seleksi karyawan dan sebuah sistem komputerisasi. Sistem merupakan hubungan antara unit yang satu dengan yang lainnya dimana unit tersebut saling berhubungan satu dengan lainya dan tidak dapat dipisahkan menuju satu kesatuan dalam rangka mencapai tujuan yang telah ditetapkan sebelumnya [7]

Berdasarkan situasi dan kondisi tersebut, peneliti merasa dalam melakukan proses seleksi penerimaan karyawan PT Gajah Tunggal Tbk perlu didukung sistem komputerisasi yang merupakan Sistem Penunjang Keputusan (SPK) yang dapat memudahkan dalam menentukan dan memilih karyawan yang sesuai kebutuhan serta kriteria perusahaan. Dalam membangun sistem komputerisasi tersebut peneliti membuat SPK dengan menggunakan metode Weighting Product (WP), dengan tujuan mempermudah perusahaan dalam menentukan siapa saja yang cocok dan sesuai untuk dijadikan karyawan yang sesuai kebutuhan.

Pengambilan keputusan (decision making) merupakan suatu tindakan untuk memilih diantara berbagai alternatif solusi untuk memecahkan masalah. Keputusan (decision) didefinisikan sebagai tindakan pilihan dan sering kali harus dilakukan untuk mengambil banyak keputusan dalam rangka sebuah proses pemecahan satu masalah [2]. Informasi dalam bentuk dashboard akan mempermudah proses pengambilan keputusan, perencanaan terpadu, terstruktur, dan transparan [1].

\section{METODE}

Dalam melakukan Penelitian ini peneliti melakukan pendekatan kualitatif, dimana data yang dikumpulkan banyak bukanlah berupa angka (kuantitatif), tetapi data tersebut berasal dari dokumen wawancara dan diskusi tentang pemahaman calon karyawan tentang kondisi kerja dilapangan, data dan catatan pribadi serta dokumen yang terkait. Penelitian ini akan mengolah data kulitatif tersebut menjadi gambaran realita empirik dibalik semua data kualitatif tersebut secara mendalam, terinci dan sejelas-jelasnya. Oleh karena itu peneliti menggunakan pendekatan kualitatif dengan cara membandingkan kecocokan antara realita empirik dengan teori yang berlaku memakai metode diskriptif. 
Alasan peneliti memilih metode diskriptif karena metode ini memiliki kemampuan dalam tahap menjelaskan suatu kejadian yang sedang terjadi. Penelitian yang peneliti buat ini bertujuan untuk menjelaskan suatu kondisi yang terjadi saat ini dengan prosedur ilmiah untuk menyelesaikan masalah secara ilmiah [6]

Metode pengumpulan data yang dilakukan dalam penelitian ini yaitu:

\subsection{Metode Pengumpulan Data}

Metode pengumpulan informasi/data merupakan teknik atau cara yang dilakukan oleh peneliti untuk mengumpulkan informasi/data [5]. Metode pengumpulan informasi/data yang digunakan peneliti adalah metode campuran dimana proses pengumpulan informasi/data dilakukan dengan cara menyusun beberapa pertanyaan dan disebarkan untuk dijawab oleh nara sumber yang telah ditentukan dan melakukan kegiatan wawancara. Teknik pengambilan contoh data dengan purposive sampling adalah sebuah teknik pengambilan sampel dengan menentukan responden yang telah dipilih oleh peneliti berdasarkan spesifikasi yang dimiliki contoh data tersebut [3].

\section{Metode Observasi}

adalah sebuah proses pengamatan langsung terhadap profil organisasi dan objek penelitian. Teknik observasi yang dilakukan peneliti adalah observasi berstruktur yaitu menyiapkan list kebutuhan informasi/data dan sumber informasi/data berkaitan dengan penelitian yang peneliti lakukan.

\section{Metode Wawancara}

adalah sebuah teknik pengumpulan informasi/data yang dilakukan dengan tatap muka dan berbincang yang dilakukan penulis dengan narasumber berdasarkan waktu yang telah ditentukan dan disepakati terlebih dahulu, sehingga data yang diperoleh langsung dari sumber datanya.

Pada proses wawancara, peneliti mengajukan beberapa pertanyaan yaitu:

A. Pertanyaan untuk pimpinan perusahaan

- Karyawan seperti apa yang dicari perusahaan?

- Apakah ada peraturan dari pemerintah setempat yang harus dipenuhi perusahaan?

B. Pertanyaan untuk manajer HRD

- Lebih penting tingkat kepandaian atau semangat bekerja?

- Apakah ada syarat minimal nilai kepandaian dalam melakukan seleksi karyawan?

- Selain kepandaian, faktor apa lagi yang perlu diperhatikan dalam proses seleksi karyawan?

C. Pertanyaan untuk pengguna sistem

- Apakah pengguna terbiasa menggunakan aplikasi komputerisasi?

- Apakah sistem berbasis web atau sistem berbasis mobile yang lebih diingkan pengguna?

- Tampilan aplikasi yang seperti apa yang diinginkan pengguna? 


\section{Metode Dokumentasi}

Peneliti juga menerima informasi/data dari sumber data sekunder yaitu dokumen, dan data-data yang berhubungan dengan dokumen perusahaan PT. Gajah Tunggal Tbk berupa, mulai dari sejarah perusahaan serta Visi dan Misi sampai dengan data karyawan yang ada saat ini serta riwayat kasus yang berhubungan dengan ketenagakerjaan.

\subsection{Pola Pikir dan Langkah-langkah Penelitian}

Peneliti menggunakan model pengembangan sistem water fall, yaitu proses pengembangan sistem yang menyiratkan pendekatan sistematis dan berurutan (sekuensial) pada proses pembangunan sistem, dimana proses pengembangan sistem mengalir kebawah, seakan terlihat bagai air terjun [4].

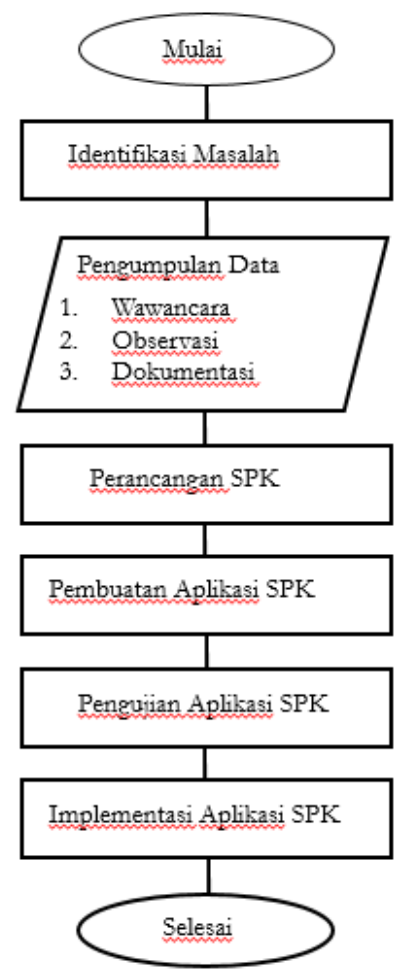

Gambar 1. Langkah-Langkah Penelitian

\subsection{Analisis SPK Metode WP (Weighted Product)}

Keterangan bobot kriteria
a) Sangat Rendah $=1$
d) Baik $=4$
b) Rendah $=2$
e) Sangat Baik $=5$
c) Cukup $=3$
Untuk menentukan nilai bobot kriteria adalah sebagai berikut: 
Nilai Bobot Kriteria $=\frac{\text { Bobot Kriteria }}{\sum \text { Bobot Kriteria }}$

Contoh : Nilai bobot tes wawancara $=\frac{3}{(3+3+4+3)}=\frac{3}{13}=0.2307$

Nilai bobot tes kemampuan dasar $=\frac{3}{(3+3+4+3)}=\frac{3}{13}=0.2307$

Nilai bobot pengalaman $=\frac{4}{(3+3+4+3)}=\frac{4}{13}=0.3076$

Nilai bobot pendidikan $=\frac{3}{(3+3+4+3)}=\frac{3}{13}=0.2307$

Untuk menentukan nilai vektor $\mathrm{S}$ adalah sebagai berikut:

Nilai vektor $\mathrm{S}=$ Nilai kriteria $\mathrm{x}$ Nilai bobot kriteria

$$
\begin{aligned}
\text { Contoh: Sapri } & =\left(90^{0.2307}\right)+\left(85^{0.2307}\right)+\left(80^{0.3076}\right)+\left(80^{0.2307}\right) \\
& =20.736+19.609+24.608+18.456 \\
& =83.409
\end{aligned}
$$

Untuk menetukan niilai vektor $\mathrm{V}$ adalah sebagai berikut:

Nilai vektor $\mathrm{V}=\frac{\text { Nilai vektor } S}{\sum \text { Nilai vektor } S}$

Contoh: Sapri $=$

83.409

$$
\begin{aligned}
& \overline{(78.142+82.952+68.548+81.211+80.435+83.409)} \\
& =\frac{83.409}{474.697} \\
& =0.1757
\end{aligned}
$$

Jadi nilai terbesar pada vektor $\mathrm{v}$ yang akan mendapatkan ranking teratas.

Tabel 1. Tabel Penerimaan Karyawan

\begin{tabular}{|c|l|c|}
\hline No & \multicolumn{1}{|c|}{ Kriteria } & Nilai \\
\hline 1 & Test wawancara & \\
\hline 2 & Test tulis & \\
\hline 3 & Pengalaman & \\
\hline 4 & Pendidikan & \\
\hline
\end{tabular}

Tabel 2. Tabel Keterangan

\begin{tabular}{|c|l|c|}
\hline No & \multicolumn{1}{|c|}{ Bobot } & Nilai \\
\hline 1 & Sangat tinggi & $75-100$ \\
\hline 2 & Tinggi & $60-100$ \\
\hline 3 & Cukup & $50-75$ \\
\hline 4 & Rendah & $0-50$ \\
\hline 5 & Sangat rendah & $0-25$ \\
\hline
\end{tabular}


Vol. 1, No. 2, September 2019

\section{HASIL DAN PEMBAHASAN}

\subsection{Sistem yang Diusulkan}

Peneliti memberikan usulan sistem yang dapat memberikan informasi perkiraan umum untuk perusahaan mengenai sistem penerimaan karyawan baru. Perancangan sistem secara umum juga dapat memberikan gambaran tentang komponen sistem penerimaan karyawan yang akan dikembangkan. Sistem yang diusulkan diharapkan dapat memecahkan permasalahan yang terjadi khusunya permasalahan penerimaan karyawan di Perusahaan PT Gajah Tunggal Tbk.

\subsection{Use Case Diagram}

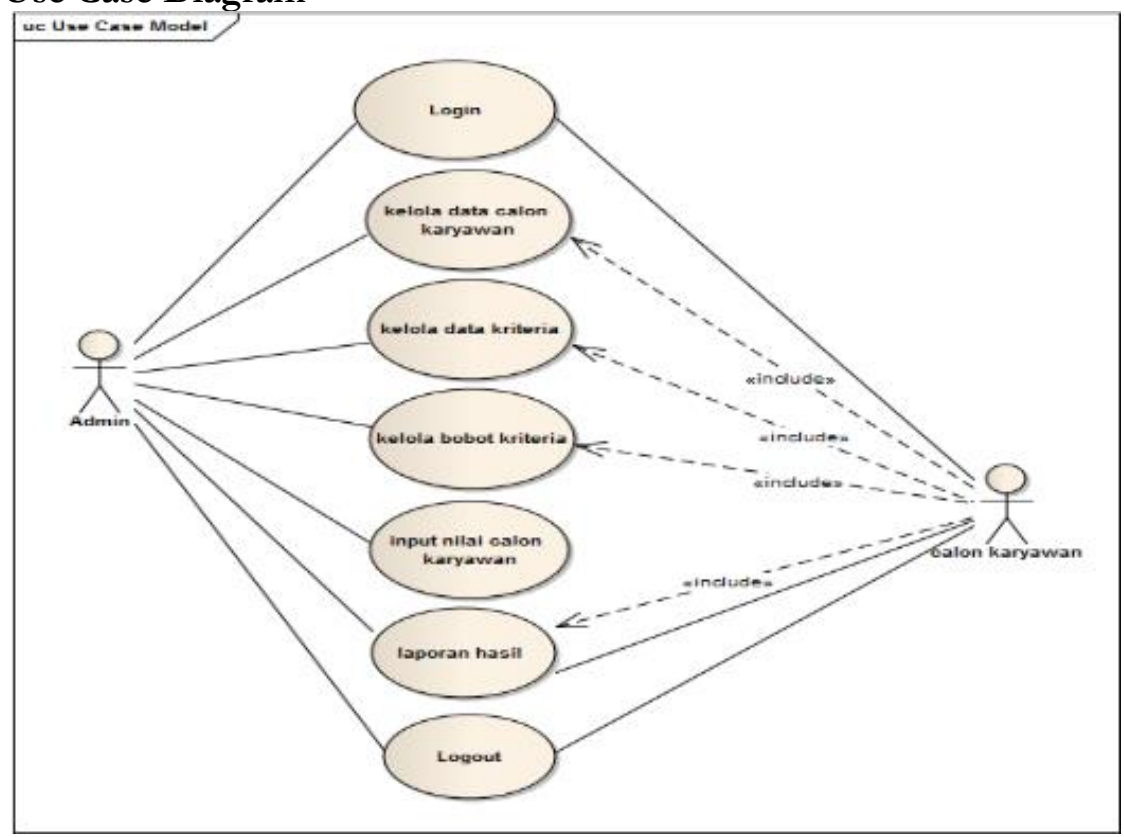

\section{Gambar 2. Use Case Diagram Usulan}

Deskripsi use case sistem yang diusulkan adalah sebagai berikut:

1. Admin akan login ke sistem.

2. Admin akan mengelola data calon karyawan (Add, Edit, View, Dellete).

3. Admin akan mengelola kriteria (Add, Edit, View, Dellete).

4. Admin akan mengelola bobot kriteria, memasukan nilai setiap kriteria.

5. Admin dapat menginput data nilai calon karyawan.

6. Admin mengelola laporan hasil evalualuasi calon karyawan.

7. Admin melakukan logout.

8. Calon karyawan login ke sistem.

9. Calon karyawan mengakses laporan hasil proses evalualuasi calon karyawan

10. Calon karyawan melakukan logout. 
Journal of Information Systems and Informatics

Vol. 1, No. 2, September 2019

p-ISSN: 2656-5935

http://journal-isi.org/index.php/isi

e-ISSN: 2656-4882

\subsection{Activity Diagram}

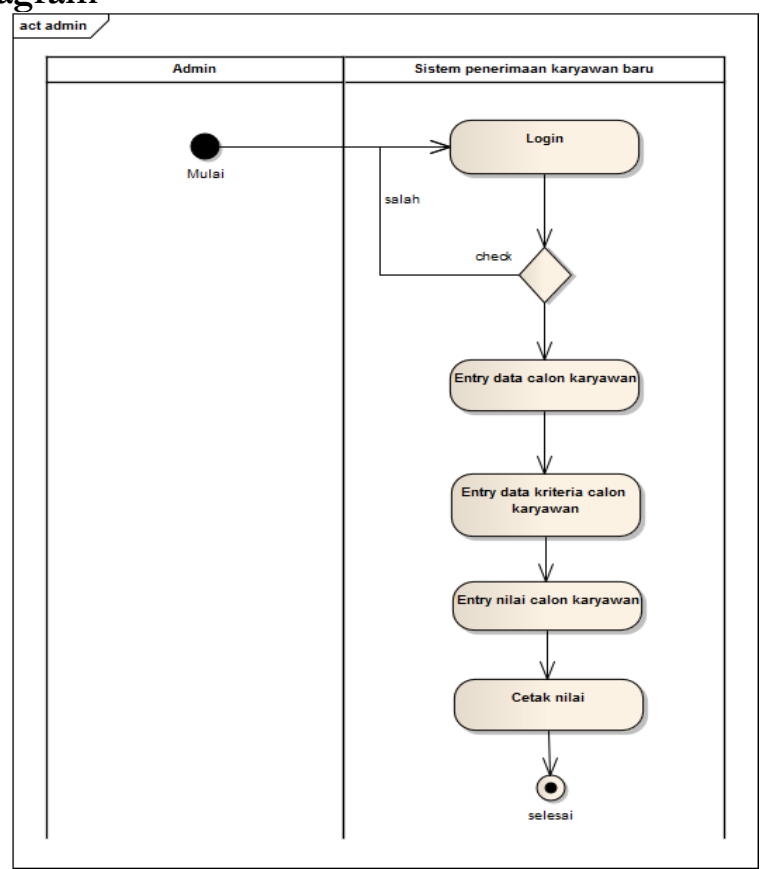

Gambar 3. Activity Diagram Admin

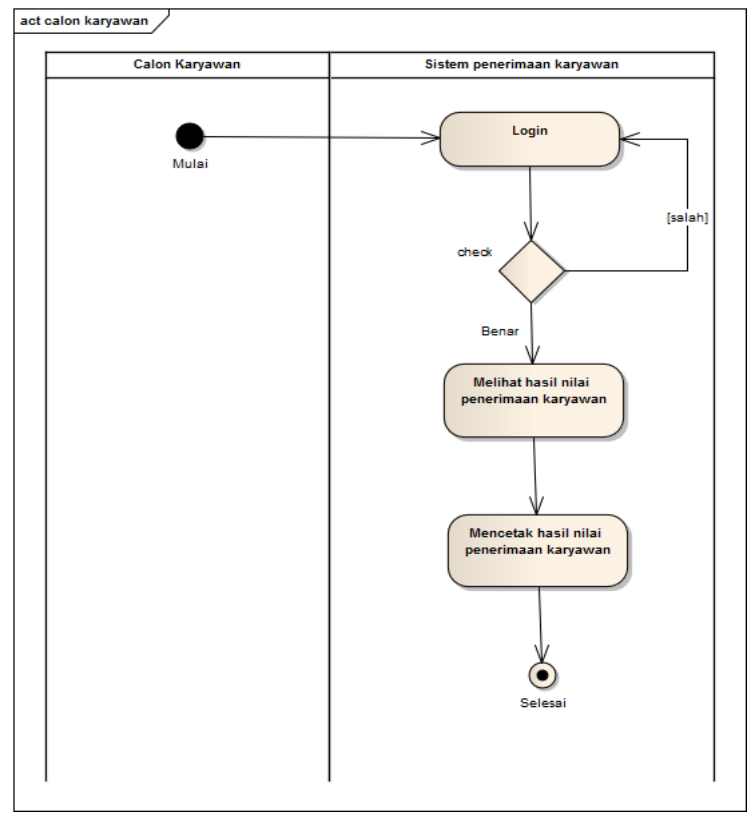

Gambar 4. Activity Diagram Calon Karyawan 
Vol. 1, No. 2, September 2019

p-ISSN: 2656-5935 http://journal-isi.org/index.php/isi e-ISSN: 2656-4882

\subsection{Sequence Diagram}

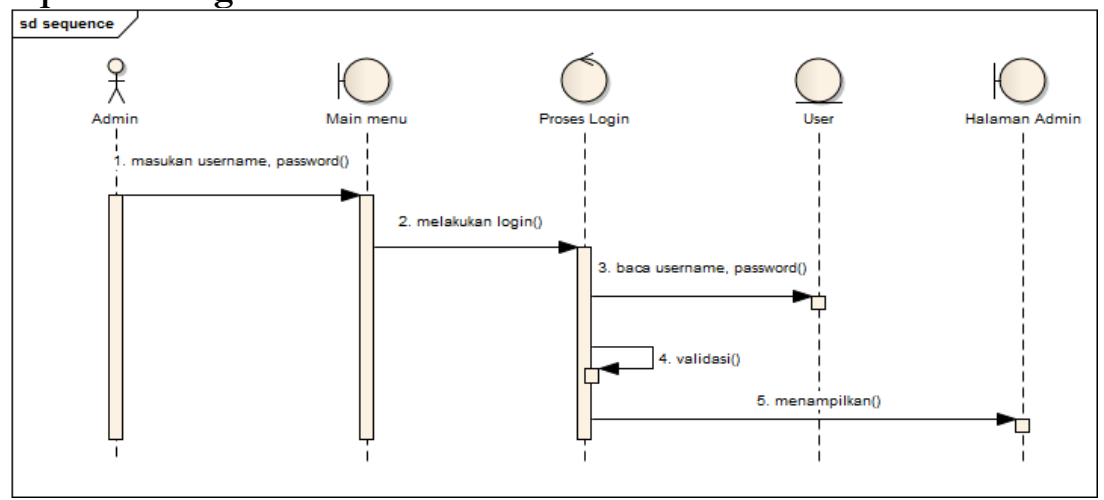

Gambar 5. Sequence Diagram Admin

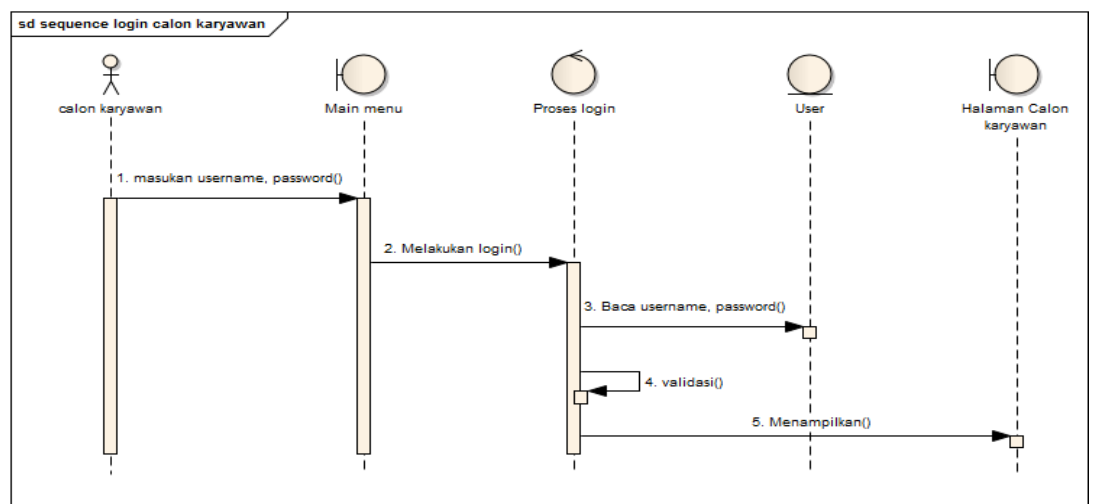

Gambar 6. Sequence Diagram Calon Karyawan

\subsection{Class Diagram}

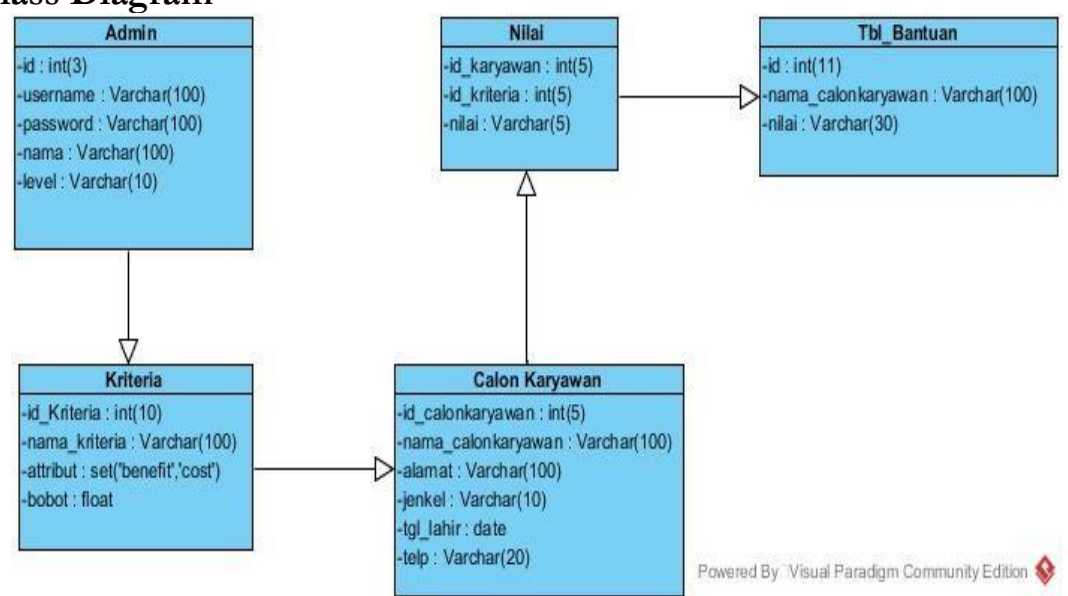

Gambar 7. Class Diagram SPK yang diusulkan 
Vol. 1, No. 2, September 2019

p-ISSN: 2656-5935 http://journal-isi.org/index.php/isi e-ISSN: 2656-4882

\subsection{User Front End/Application Layout}

A. Menu Login

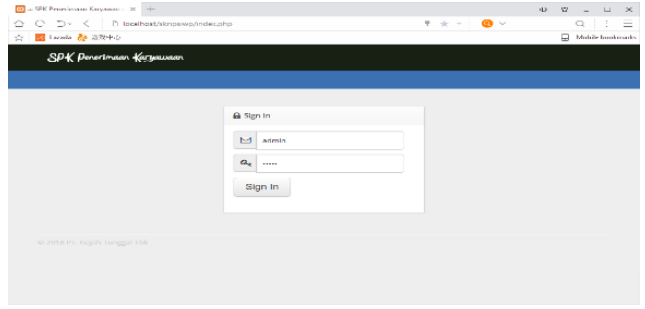

Gambar 8. Menu Login

Tampilan menu login berguna untuk masuk ke sistem penerimaan karyawan sesuai dengan hak akses yang diberikan.

\section{B. Tampilan Halaman Utama}

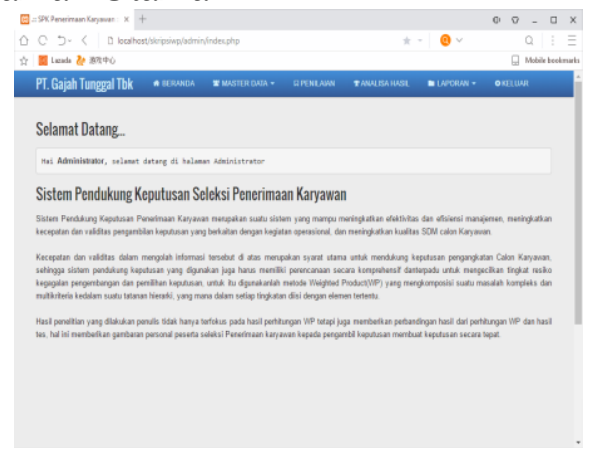

Gambar 9. Tampilan Halaman Utama

Menu utama sistem penerimaan karyawan yang dikembangkan berisi informasi tentang sistem penerimaan karyawan antara lain, beranda, master data, penilaian, hasil analisa, pelaporan, dan log-out.

\section{Tampilan Menu Master Data}

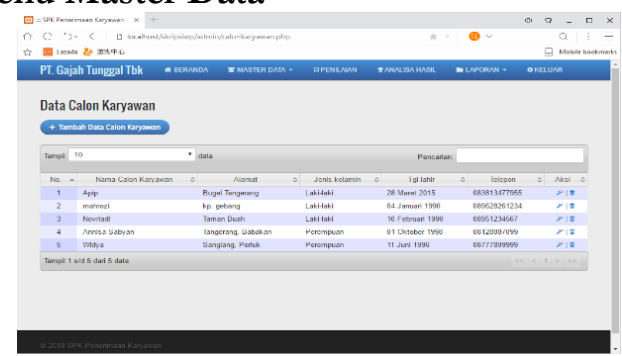

Gambar 10. Tampilan Master Data

Menu master data adalah sebuah menu yang akan menampilkan data calon karyawan, mengedit, menghapus dan menambah data calon karyawan di PT Gajah Tunggal Tbk. 
Journal of Information Systems and Informatics

Vol. 1, No. 2, September 2019

p-ISSN: 2656-5935

http://journal-isi.org/index.php/isi

e-ISSN: 2656-4882

\section{Tampilan Master Data Kriteria}

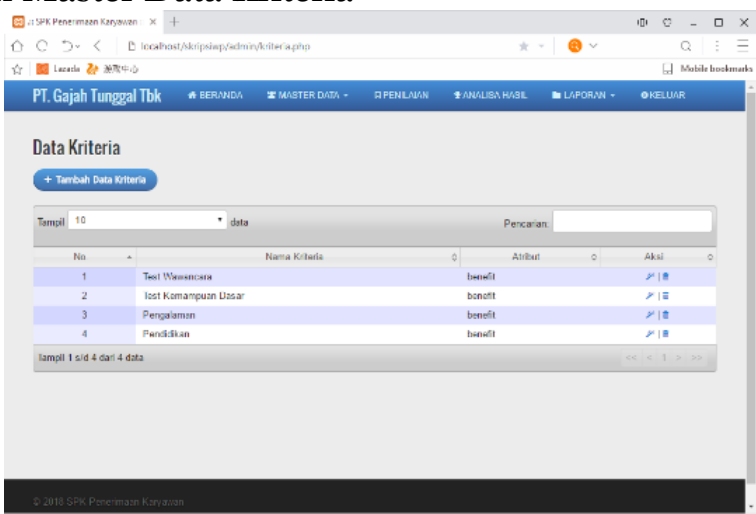

Gambar 11. Tampilan menu data kriteria

\section{E. Tampilan Manu Analisis Hasil}

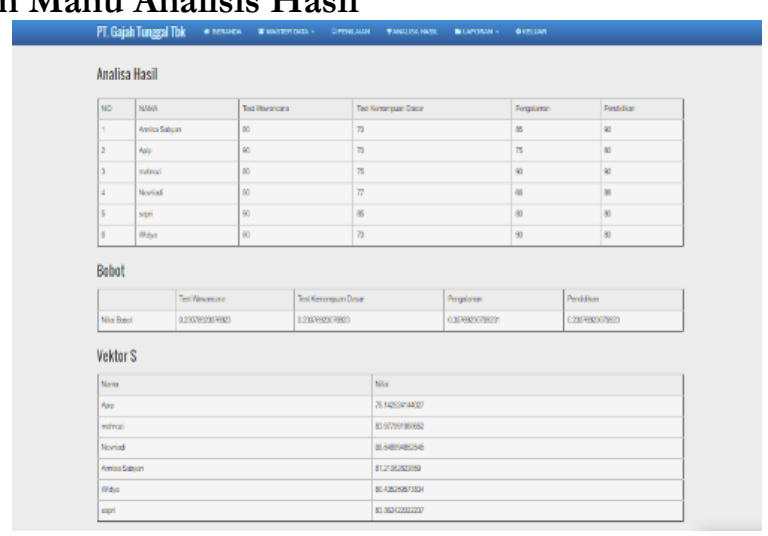

Gambar 12. Analisa hasil

\section{F. Tampilan Laporan Rekomendasi Calon Caryawan}

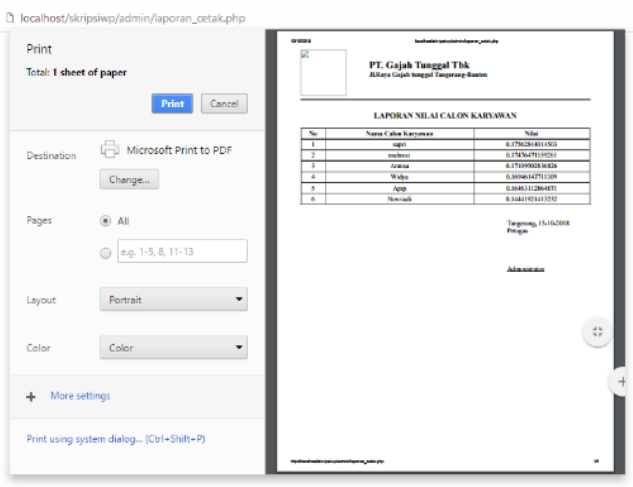

Gambar 13. Laporan Rekomendasi Calon Karyawan 
Vol. 1, No. 2, September 2019

p-ISSN: 2656-5935 http://journal-isi.org/index.php/isi e-ISSN: 2656-4882

\section{G. Pengujian Aplikasi SPK}

Tabel 3. Tabel Black Box Testing

\begin{tabular}{|c|c|c|c|c|c|}
\hline No & Pengujian & $\begin{array}{l}\text { Skenario } \\
\text { Pengujian }\end{array}$ & $\begin{array}{c}\text { Detail } \\
\text { Pengujian }\end{array}$ & $\begin{array}{c}\text { Hasil } \\
\text { pengujian }\end{array}$ & Hasil Pengujian \\
\hline 1 & \multirow[t]{2}{*}{$\begin{array}{l}\text { Menguji hak akses } \\
\text { pengguna }\end{array}$} & \multirow{2}{*}{$\begin{array}{l}\text { Mengisi user name, } \\
\text { password dengan } \\
\text { tidak legkap lalu } \\
\text { click log-in }\end{array}$} & $\begin{array}{l}\text { Isi user name } \\
\text { tanpa password }\end{array}$ & \multirow{2}{*}{$\begin{array}{c}\text { Sistem } \\
\text { menolak } \\
\text { akses login }\end{array}$} & $\begin{array}{c}\text { Sesuai harapan } \\
\text { (valid) }\end{array}$ \\
\hline 2 & & & $\begin{array}{l}\text { Isi password } \\
\text { tanpa user } \\
\text { name }\end{array}$ & & $\begin{array}{c}\text { Sesuai harapan } \\
\text { (valid) }\end{array}$ \\
\hline 3 & $\begin{array}{l}\text { Menguji fungsi } \\
\text { entry/edit/ delete } \\
\text { data }\end{array}$ & $\begin{array}{l}\text { Mengisi user name, } \\
\text { password lalu click } \\
\text { log-in. } \\
\text { Click detail }\end{array}$ & $\begin{array}{c}\text { Masuk menu } \\
\text { daftar record, } \\
\text { masukan data } \\
\text { kriteria }\end{array}$ & $\begin{array}{c}\text { Dapat } \\
\text { melakukan } \\
\text { entry/edit/ } \\
\text { delete data }\end{array}$ & $\begin{array}{c}\text { Sesuai harapan } \\
\text { (valid) }\end{array}$ \\
\hline 4 & $\begin{array}{l}\text { Menguji laporan } \\
\text { yang dihasilkan } \\
\text { sistem }\end{array}$ & $\begin{array}{l}\text { Mengisi user name, } \\
\text { password lalu click } \\
\text { log-in. } \\
\text { Click report }\end{array}$ & $\begin{array}{c}\text { Masuk ke } \\
\text { menu Report/ } \\
\text { laporan }\end{array}$ & $\begin{array}{c}\text { Menampilkan } \\
\text { /mencetak } \\
\text { laporan sesuai } \\
\text { kebutuhan }\end{array}$ & $\begin{array}{c}\text { Sesuai harapan } \\
\text { (valid) }\end{array}$ \\
\hline
\end{tabular}

\section{CONCLUSION}

Berdasarkan implementasi dan pengujian kesimpulan dari penelitian ini antara lain:

1. Penggunaan metode WP untuk sistem penerimaan karyawan cukup efektif membantu HRD dalam proses perekrutan sesuai kebutuhan perusahaan.

2. Dengan menerapkan SPK metode WP, PT Gajah Tunggal Tbk memiliki standard bobot yang tetap pada proses penerimaan karyawan baru, sehingga kulitas karyawan dapat mendekati pada setiap batch penerimaan.

3. Dengan menerapkan metode WP memudahkan perusahaan mendapatkan calon karyawan yang memenuhi standar dan berkompeten.

4. Rancang bangun SPK penerimaan karyawan yang dikembangkan telah memberikan manfaat, kemudahan dan dapat dijadikan referensi pengembangan sistem perusahaan lain yang sejenis, karena sistem yang dikembagkan dapat memberikan solusi dalam mendapatkan calon karyawan yang memenuhi standar perusahaan.

\section{REFERENCES}

[1] Carli, R., Albino, V., Dotoli, M., Mummolo, G., Savino, M., A Dashboard and Decision Support Tool for The Energy Governance of Smart Cities. Jurnal IEEE, DOI: 10.1109/EEMS. 2015.7175846, Date of Conference: 9-10 July 2015. http://ieeexplore.ieee.org/document/7175846/

[2] McLeod, R., George, P., Schell., Management Information System, 10th ed. Dialihbahasakan oleh Yulianto, A, Akbar., Afia, R, Fitriati., Jakarta, Salemba Empat, pp.326, 2012.

[3] Nasution, S. Metode Research. Jakarta: Bumi Aksara, pp.98, 2009.

[4] Pressman, S, Roger. Software Engineering: A Practitioner's Approach, 7th ed. Dialihbahasakan oleh Nugroho, Adi, et.al. Yogyakarta: ANDI, pp.46, 2012

[5] Sudaryono, "Metodologi Riset di Bidang IT: Panduan Praktis, Teori dan Contoh Kasus", Yogyakarta, Andi Offset, pp.125, 2015.

[6] Sugiyono, "Metode Penelitian Manajemen", Alfabeta, 2013.

[7] Rusdiana., Irfan, M., Sistem Informasi Manajemen. Bandung, CV Pustaka Setia, pp.3-5, 2014. 